\title{
DNA Fingerprinting and Assessment of Genetic Diversity among 22 Cowpea [Vigna unguiculata (L.) Walp] Varieties Grown in Ghana
}

\author{
Benjamin A. Danso', Daniel K. Dzidzienyo', Ruth N. A. Prempeh², Marian D. Quain² \\ ${ }^{1}$ West Africa Centre for Crop Improvement, University of Ghana, Accra, Ghana \\ ${ }^{2}$ CSIR-Crops Research Institute, Kumasi, Ghana \\ Email: abdanso@wacci.ug.edu.gh,ddzidzienyo@wacci.ug.edu.gh, ginathompsongh@yahoo.com, marianquain@hotmail.com
}

How to cite this paper: Danso, B.A., Dzidzienyo, D.K., Prempeh, R.N.A. and Quain, M.D. (2018) DNA Fingerprinting and Assessment of Genetic Diversity among 22 Cowpea [Vigna unguiculata (L.) Walp] Varieties Grown in Ghana. Open Access Library Journal, 5: e4938.

https://doi.org/10.4236/oalib.1104938

Received: September 22, 2018

Accepted: December 18, 2018

Published: December 21, 2018

Copyright $\odot 2018$ by authors and Open Access Library Inc.

This work is licensed under the Creative Commons Attribution International License (CC BY 4.0).

http://creativecommons.org/licenses/by/4.0/

\begin{abstract}
Identification of varieties based on only morphological traits is limited by the influence of environment on such morphological traits. Deoxyribonucleic acid (DNA) fingerprinting offers an efficient system of identifying varieties at the DNA level without any environmental interference. This work used 20 Simple Sequence Repeat (SSR) markers to characterise twenty-two cowpea [Vigna unguiculata (L.) Walp] varieties for the purposes of varietal protection and further assessed for genetic diversity. This study was conducted at the Biotechnology laboratory of Council for Scientific and Industrial Research-Crops Research Institute, Ghana (CSIR-CRI). The varieties were made up of 15 cultivars released by CSIR-CRI, Ghana, 5 cultivars released by CSIR-Savannah Agricultural Research Institute, Ghana (SARI), 1 advanced line, 1 landrace and 1 exotic variety. Nineteen out of the 20 SSR markers used in this study were polymorphic. These polymorphic primers generated a range of 1 to 6 alleles per primer with polymorphic information content (PIC) varying from 0.107 (SSR-6608) to 0.656 (SSR-6613). Allele frequency ranged from 0.136 (SSR6371) to 0.841 (SSR-6608) with mean of 0.445 . With the aid of Darwin software, dissimilarity matrix and a dendrogram were generated from the molecular data to evaluate and group the varieties based on genetic resemblance. Three pairs of varieties (Agyenkwa and Adom; Hewale and Ayiyi; Zamzam and Hewale) recorded the highest genetic distance of 0.652 each. The genetic information gathered for each variety has been made available to the breeding institutions. The genetic diversity detected among the varieties fingerprinted will be helpful to plant breeders in selecting parents for future cowpea improvement programmes.
\end{abstract}

\section{Subject Areas}

Agricultural Science, Biotechnology, Genetics 


\section{Keywords}

Cowpea, Characterization, Diversity, Simple Sequence Repeats

\section{Introduction}

Cowpea [Vigna unguiculata (L.) Walp] is an early maturing crop that tolerates poor soil fertility and water stress [1]. This makes it an important food crop in areas hard hit with climate change, famine, poor soil fertility, poverty and high population growth rate [1] [2]. Cowpea has evolved from native wild types and its genetic diversity is greater than that of any other crop in the dry African savannah [3]. However, the cultivated cowpea has been shown to have a narrow genetic base suggesting the crop went through a "genetic bottleneck" during domestication [4]. Awareness of existing plant genetic diversity in the cowpea germplasm is therefore fundamental for effective management of cowpea genetic resources [5]. The establishment of the forensic identity of crop varieties has become vital for protecting plant breeders' and farmers' right following the enactment of the Convention of Biodiversity Conservation particularly in developing countries [6]. DNA fingerprinting which is also known as molecular characterization is a useful tool for genotype identification, diversity studies and associating molecular markers to phenotypic traits [7]. Fingerprinting with molecular markers allows precise, objective and rapid variety identification of plant varieties [5]. Unlike phenotypic based markers, molecular markers are stable and detectable in all tissues regardless of growth differentiation, development, pleitropic effect, epistatic effects and not confounded to environment where they grow [6] [8]. SSRs, also known as Microsatellites, are co-dominant markers that are routinely used to study genetic diversity in different crop species [6]. These markers occur at high frequency and appear to be distributed throughout the genome of higher plants [8].

Several successful molecular characterization and genetic diversity study works have been conducted on many cowpea accessions in the past using SSR markers in Ghana and the world at large [6] [9] [10] [11] [12]. However, new varieties have been released by the CSIR-Crops Research Institute of Ghana (CRI) and CSIRSavannah Research Institute of Ghana (SARI) in recent times and there is therefore the need to record a forensic fingerprint of these newly released varieties together with old varieties using SSR markers for purposes of conservation, patent rights and genetic diversity studies. The aim of this study was therefore to fingerprint and evaluate genetic diversity among 22 cowpea varieties grown in Ghana, including four newly released varieties with the aid of 20 SSR markers.

\section{Materials and Methods}

\subsection{Planting Materials}

Seeds of 22 cowpea varieties were collected from the gene banks of CSIR-SARI 
and CSIR-CRI, sowed and nurtured in sterile soil in a greenhouse. Germplasm for this study was composed of 15 cultivars released by CSIR-CRI, 4 cultivars released by CSIR-SARI, 1 advanced line from CSIR-SARI, 1 landrace and 1 exotic variety grown in Ghana (Table 1 ).

\subsection{Deoxyribonucleic Acid (DNA) Extraction}

The laboratory studies were conducted in the Biotechnology laboratory of CSIR-CRI, Kumasi. Leaf explants were harvested from the 22 cowpea varieties two weeks after planting and kept in liquid nitrogen. Total DNA was extracted according to the prescribed protocol of the DNeasy ${ }^{\text {ma }}$ Plant Mini extraction kit (Qiagen, Germany). DNA quality was checked using $0.8 \%(\mathrm{w} / \mathrm{v})$ agarose gel electrophoresis. The concentration of the DNA was determined on a Nanodrop (spectrophotometer 2000C). The genomic DNA samples were diluted to a final concentration of $20 \mathrm{ng} / \mu \mathrm{L}$ with $1 \times$ TE buffer (10 mM Tris-HC1, pH 8.0;1 mM EDTA) and stored at $-20^{\circ} \mathrm{C}$ for further use.

Table 1. Cowpea varieties used for the study.

\begin{tabular}{|c|c|c|c|c|c|}
\hline No. & Local Name & Accession Name & $\begin{array}{c}\text { Source of } \\
\text { material }\end{array}$ & Status & $\begin{array}{c}\text { Year of Release } \\
\text { in Ghana }\end{array}$ \\
\hline 1 & Hewale & IT93K-192-4 & CSIR-CRI & Released variety & 2012 \\
\hline 2 & Asomdwoe & IT94K-410-2 & CSIR-CRI & Released variety & 2012 \\
\hline 3 & Videza & IT95K-142-20 & CSIR-CRI & Released variety & 2012 \\
\hline 4 & Nhyira & IT87D-611-3 & CSIR-CRI & Released variety & 2005 \\
\hline 5 & Tona & IT87D-2075 & CSIR-CRI & Released variety & 2005 \\
\hline 6 & Asetenapa & IT32D-1951 & CSIR-CRI & Released variety & 1999 \\
\hline 7 & Adom & CR-06-07 & CSIR-CRI & Released variety & 1999 \\
\hline 8 & Ayiyi & IT83S-728-13 & CSIR-CRI & Released variety & 1992 \\
\hline 9 & Bengpla & IT83S-818 & CSIR-CRI & Released variety & 1992 \\
\hline 10 & Asontem & IT82D-32 & CSIR-CRI & Released variety & 1999 \\
\hline 11 & Soronko & TVX2724-OIF & CSIR-CRI & Released variety & 1999 \\
\hline 12 & Agyenkwa & $11(8)-1$ & CSIR-CRI & Released variety & 2015 \\
\hline 13 & Zamzam & $11(9)-5$ & CSIR-CRI & Released variety & 2015 \\
\hline 14 & Hansadua & $11(9)-2$ & CSIR-CRI & Released variety & 2015 \\
\hline 15 & Nketewade & $11(9)-3$ & CSIR-CRI & Released variety & 2015 \\
\hline 16 & Zaayura & SARC4-75 & CSIR-SARI & Released variety & 2008 \\
\hline 17 & Songotra & IT97K-499-35 & CSIR-SARI & Released variety & 2008 \\
\hline 18 & Padi-Tuya & SARC3-122-2 & CSIR-SARI & Released variety & 2008 \\
\hline 19 & Apabgaala & ITXP48-2 & CSIR-SARI & Released variety & 2003 \\
\hline 20 & & SARC-1-57-2 & CSIR-SARI & Advanced line & \\
\hline 21 & Sanzi & & Northern Ghana & Landrace & \\
\hline 22 & Bra-01 & & Brazil & Exotic & \\
\hline
\end{tabular}




\subsection{Polymerase Chain Reaction Using SSR Markers}

A total of 20 SSR primers (Table 2) were used to fingerprint the 22 cowpea varieties. Information about the primers was obtained from the SSR panel reported by Timko [13]. The primers were synthesized by Inqaba Biotechnical Industries Ltd., Pretoria, South Africa. Polymerase chain reaction (PCR) amplification was conducted in $20 \mu \mathrm{l}$ volume tubes. Each PCR reaction contained $6 \mu \mathrm{l}$ "One Taq Quick-Load 2x Master Mix" (composed of $20 \mathrm{mM}$ Tris- $\mathrm{HCl}, 1.8 \mathrm{mM} \mathrm{MgCl}, 22$ $\mathrm{mM} \mathrm{NH}_{4} \mathrm{Cl}, 22 \mathrm{mM} \mathrm{KCl}, 0.2 \mathrm{mM}$ dNTPS and 25 units/ml One Taq DNA Polymerase), $2.0 \mu \mathrm{l}$ Molecular Grade Distilled Water (MGDW), $0.5 \mu \mathrm{l}$ of each primer pair and $2 \mathrm{ng} / \mu \mathrm{L}$ of genomic DNA sample to make a total volume of $10 \mu \mathrm{l}$. The PCR amplifications were performed in a thermal cycler C1000 (Seegene, Korea). The thermal cycler was set to initial denaturation at $94^{\circ} \mathrm{C}$ for 1 minute followed by 35 cycles of denaturation for 30 seconds at $94^{\circ} \mathrm{C}$, annealing at $55^{\circ} \mathrm{C}$ for 30 seconds, extension at $72^{\circ} \mathrm{C}$ for 1 minute and ended with final extension at $72^{\circ} \mathrm{C}$ for 10 minutes.

Table 2. SSR primers used for molecular characterization and their sequences

\begin{tabular}{|c|c|c|c|c|c|c|}
\hline No. & SSR Name & $\begin{array}{l}\text { Original } \\
\text { Name }\end{array}$ & Left Sequence & Right Sequence & $\begin{array}{c}\text { Annealing } \\
\text { Temperature } \\
\left({ }^{\circ} \mathrm{C}\right)\end{array}$ & $\begin{array}{l}\text { Product } \\
\text { Size (bp) }\end{array}$ \\
\hline 1 & SSR-6265 & CP215/CP216 & CAGAAGCGGTGAAAATTCAAC & GCATGTTGCTTTGACAATGG & 55 & 239 \\
\hline 2 & SSR-6258 & CP201/CP202 & GGTTTCCTAGTTGGGAAGGAA & ATTATGCCATGGAGGGTTCA & 55 & 260 \\
\hline 3 & SSR-6243 & $\mathrm{CP} 171 / \mathrm{CP} 172$ & GTAGGGAGTTGGCCACGATA & CAACCGATGTAAAAAGTGGACA & 55 & 176 \\
\hline 4 & SSR-6218 & CP117/CP118 & GTGGAAGGAATGGGTCCAG & AGGAAATTTGCATTCCCTTGT & 55 & 287 \\
\hline 5 & SSR-6217 & CP115/CP116 & GGGAGTGCTCCGGAAAGT & TTCCCTATGAACTGGGAGATCTAT & 55 & 294 \\
\hline 6 & SSR-6353 & СР397/CP398 & TCATGGGTTAAATTTGCTTCAA & AAACCATGTGGTTGTTGCAC & 50.9 & 109 \\
\hline 7 & SSR-6352 & СР395/СР396 & GTTGTGAGCTTCCCCAGATG & AATTTTGAACCCACCACCAG & 55 & 127 \\
\hline 9 & SSR-6323 & CP333/CP334 & CAAAGGGTCATCAGGATTGG & TTTAAGCAGCCAAGCAGTTGT & 55 & 218 \\
\hline 10 & SSR-6277 & $\mathrm{CP} 239 / \mathrm{CP} 240$ & CACCCCCGTACACACACAC & CACTTAAATTTTCACCAGGCATT & 50.9 & 157 \\
\hline 11 & SSR-6436 & CP573/CP574 & GCAGAATCCTTGTGAACCTG & TTTCGCAATATGCCCTTTTC & 50.9 & 280 \\
\hline 12 & SSR-6375 & $\mathrm{CP} 443 / \mathrm{CP} 444$ & GCTCGGATATGGTCCTGAAA & TCAGTGTCAGCACCATACCC & 55 & 293 \\
\hline 13 & SSR-6371 & $\mathrm{CP} 435 / \mathrm{CP} 436$ & TGCTCATCGTGCTTTGTCTT & CACTTCAGACTTAGAGCGAAGAAA & 55 & 189 \\
\hline 14 & SSR-6370 & $\mathrm{CP} 433 / \mathrm{CP} 434$ & CAACTTCACAGCССТCACAA & TTGAAGGTATGGCCTTTTGTTT & 55 & 253 \\
\hline 15 & SSR-6356 & CP403/CP404 & TGCAATATGGACCAGAAGAAA & ATGCCCCAACAACAACATTT & 55 & 158 \\
\hline 16 & SSR-6613 & Y31 & CTATTGGAATCTTGCCGTTG & CTTTACCTTTATGCAAACCAATTC & 55 & 333 \\
\hline 17 & SSR-6608 & Y26 & CTAAATTATAATATTCGTCGGTC & GGTTAAGGAAAAGAGGGTAGG & 55 & 299 \\
\hline 19 & SSR-6587 & Y1 & $\begin{array}{l}\text { GATATAGAATAGCATATTTAACAT } \\
\text { ATTAG }\end{array}$ & GTTGAAAGTTTGATAGTAAAGTGG & 55 & 319 \\
\hline 20 & SSR-6451 & СР605/СР606 & AAAGAGATACACATGCCTAACA & GACCAACAGCGACTTTGAGC & 55 & 142 \\
\hline
\end{tabular}




\subsection{Gel Electrophoresis}

PCR products were resolved on $6 \%(\mathrm{w} / \mathrm{v})$ polyacrylamide gel electrophoresis (PAGE) in $1 \mathrm{X}$ Tris/borate/EDTA buffer stained with 0.5\% Ethidium bromide (Criterion cell model, vertical centrion tank) for 1 hour 30 minutes at a voltage of $80 \mathrm{~V}$. The gel was photographed under Ultraviolet light with the aid of Alpha Innotech Multimage ${ }^{\mathrm{TM}}$ Light Cabinet for further analysis.

\subsection{Scoring of Bands and Data Analysis}

The bands observed on the gels after staining were scored on the basis of presence/absence (1/0) with the aid of the Alpha Imager version 3.41 software along with a 100-bp DNA ladder (Invitrogen ${ }^{\oplus}$ ) to identify the molecular-weight of the DNA samples. Following the gel scoring, the molecular data was fed into Darwin software [14] to generate a dissimilarity matrix and a dendrogram.

\section{Results}

The primers generated a total of 481 bands across the selected varieties out of which 428 (88.98\%) were polymorphic. Only 1 (SSR 6336) out of the 20 primers did not show polymorphism among the varieties, and therefore was excluded from the analysis. A representative picture of the amplification product of primer SSR6243 showing pattern of allelic bands across the 22 cowpea varieties on $6 \%$ polyacrylamide gel is presented in Figure 1.

The size of amplified alleles ranged from $90 \mathrm{bp}$ to $391 \mathrm{bp}$ (Table 3). The primers SSR-6613 and SSR-6608 recorded the highest and lowest number of polymorphic bands of 79 and 5 respectively. The number of alleles varied from 1 to 6. The allele frequency ranged from 0.136 (SSR-6371 to 0.841 (SSR-6608) with mean of 0.445 among the varieties. The polymorphic information content (PIC) representing the allele diversity for a specific locus ranged from 0.107 (SSR-6608) to 0.656 (SSR-6613) with a mean of 0.293 .

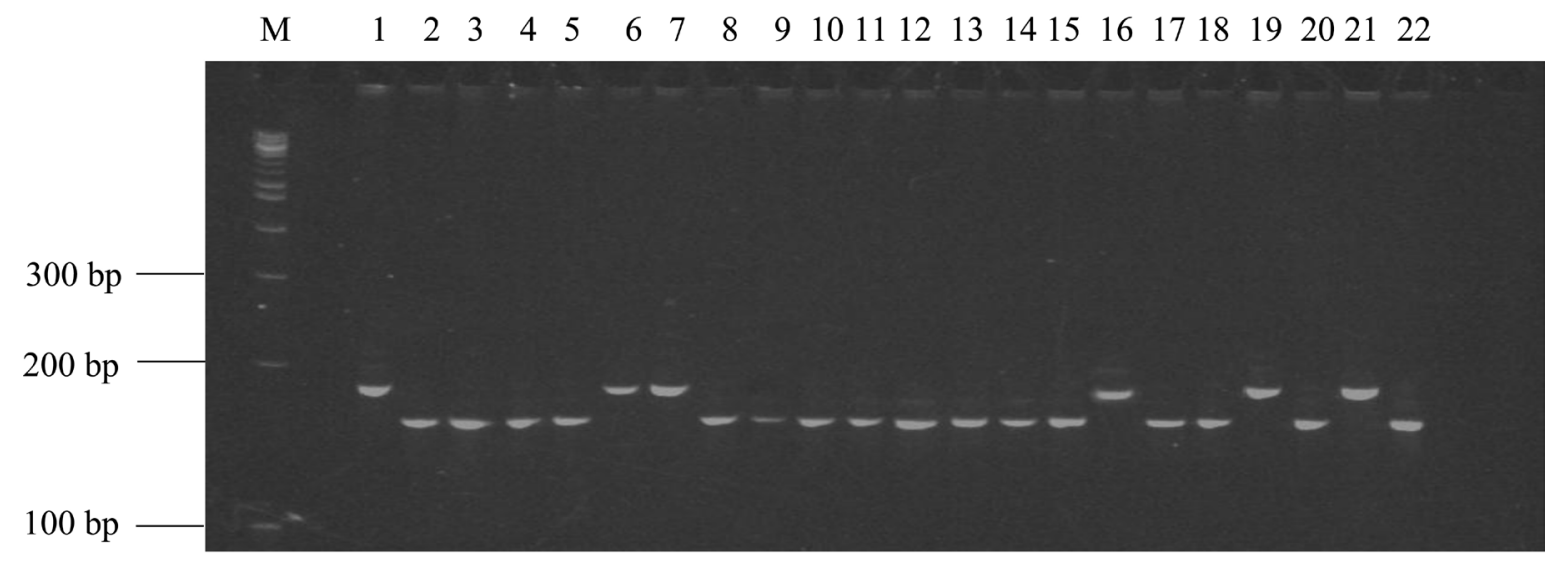

Figure 1. SSR 6243 marker scored on ethidium bromide stained PAGE gel (6\%) for 22 cowpea varieties $\mathrm{M}=100 \mathrm{bp}$ ladder; 1 = SARC-1-57-2; 2 = Apabgaala; $3=$ Nhyira; 4 = Hewale; $5=$ Asomdwee; $6=$ Adom; $7=$ Soronko; $8=$ Bengpla; 9 = Hansadua; 10 = Agyenkwa; 11 = Padi-Tuya; 12 = Zaayura; 13 = Nketewade;14 = Zamzam;15 = Ayiyi; 16 = Songotra $17=$ Videza; $18=$ Asontem; $19=$ Tona; $20=$ Asetenapa $21=$ Sanzi; $22=$ Bra 01 . 
Table 3. Resolving power analysis of SSR primers.

\begin{tabular}{|c|c|c|c|c|c|c|}
\hline Primer & $\begin{array}{l}\text { Allele size range } \\
\text { (bp) }\end{array}$ & No. of alleles & Allele frequency & $\begin{array}{c}\text { Number of } \\
\text { bands }\end{array}$ & $\begin{array}{c}\text { Number of } \\
\text { Polymorphic bands }\end{array}$ & $\begin{array}{c}\text { Polymorphic Information } \\
\text { Content (PIC) }\end{array}$ \\
\hline SSR-6265 & $217-282$ & 5 & 0.445 & 49 & 49 & 0.631 \\
\hline SSR-6258 & $195-269$ & 2 & 0.523 & 23 & 21 & 0.242 \\
\hline SSR-6243 & $165-187$ & 2 & 0.5 & 22 & 20 & 0.202 \\
\hline SSR-6218 & $149-287$ & 2 & 0.409 & 18 & 16 & 0.266 \\
\hline SSR-6217 & $230-294$ & 2 & 0.341 & 15 & 15 & 0.242 \\
\hline SSR-6353 & $90-115$ & 2 & 0.523 & 23 & 22 & 0.199 \\
\hline SSR-6352 & $113-141$ & 3 & 0.257 & 17 & 17 & 0.246 \\
\hline SSR-6323 & $220-285$ & 3 & 0.348 & 23 & 22 & 0.331 \\
\hline SSR-6277 & 114 & 1 & 0.318 & 7 & 7 & 0.34 \\
\hline SSR-6436 & $266-370$ & 3 & 0.454 & 30 & 29 & 0.405 \\
\hline SSR-6375 & $296-333$ & 2 & 0.522 & 23 & 22 & 0.405 \\
\hline SSR-6371 & $164-195$ & 2 & 0.136 & 6 & 6 & 0.185 \\
\hline SSR-6370 & $254-275$ & 2 & 0.386 & 17 & 14 & 0.091 \\
\hline SSR-6356 & $127-147$ & 2 & 0.5 & 22 & 22 & 0.223 \\
\hline SSR-6613 & $250-391$ & 6 & 0.598 & 79 & 79 & 0.656 \\
\hline SSR-6608 & $233-300$ & 2 & 0.841 & 37 & 5 & 0.107 \\
\hline SSR-6603 & $358-386$ & 2 & 0.477 & 21 & 20 & 0.261 \\
\hline SSR-6587 & $336-352$ & 2 & 0.409 & 18 & 14 & 0.204 \\
\hline SSR-6451 & $110-155$ & 3 & 0.469 & 31 & 28 & 0.325 \\
\hline Mean & & 2.526 & 0.445 & 25.32 & 22.53 & 0.293 \\
\hline
\end{tabular}

\section{Dissimilarity Matrix and Cluster Analysis Based on SSR Markers}

The genetic distances within pairs of the 22 varieties were evaluated in a dissimilarity matrix generated from the molecular data using Darwin software. From the dissimilarity matrix (Table 4), there was no distance between Videza and Asomdwoe which implies that the two varieties are very similar. A short distance of 0.109 was found between Zamzam and Agyenkwa while the highest distance (most divergent) was found among three pairs of varieties: Agyenkwa and Adom; Hewale and Ayiyi; Zamzam and Helwale at genetic distance of 0.652. The dendrogram grouped the 22 varieties into four major clusters (A, B, C and $D$ ) at genetic distance of 0.20 (Figure 2). Cluster A was made up of only Hewale. Cluster B had two sub-clusters diverging at genetic distance of 0.125. Sub-cluster I consisted of only Zaayura while subcluster II consisted of Asomdwoe and Videza. The third major cluster was cluster $C$ which consisted of 9 varieties grouped into two subclusters diverging at genetic distance of 0.15 . Cluster D also consisted of two sub-clusters. The first sub-cluster comprised of 5 varieties (Adom, Asontem, Tona, Nhyira and Soronko) while the second sub-cluster consisted of 3 varieties (Hasnsadua, Bengpla and Songotra). 


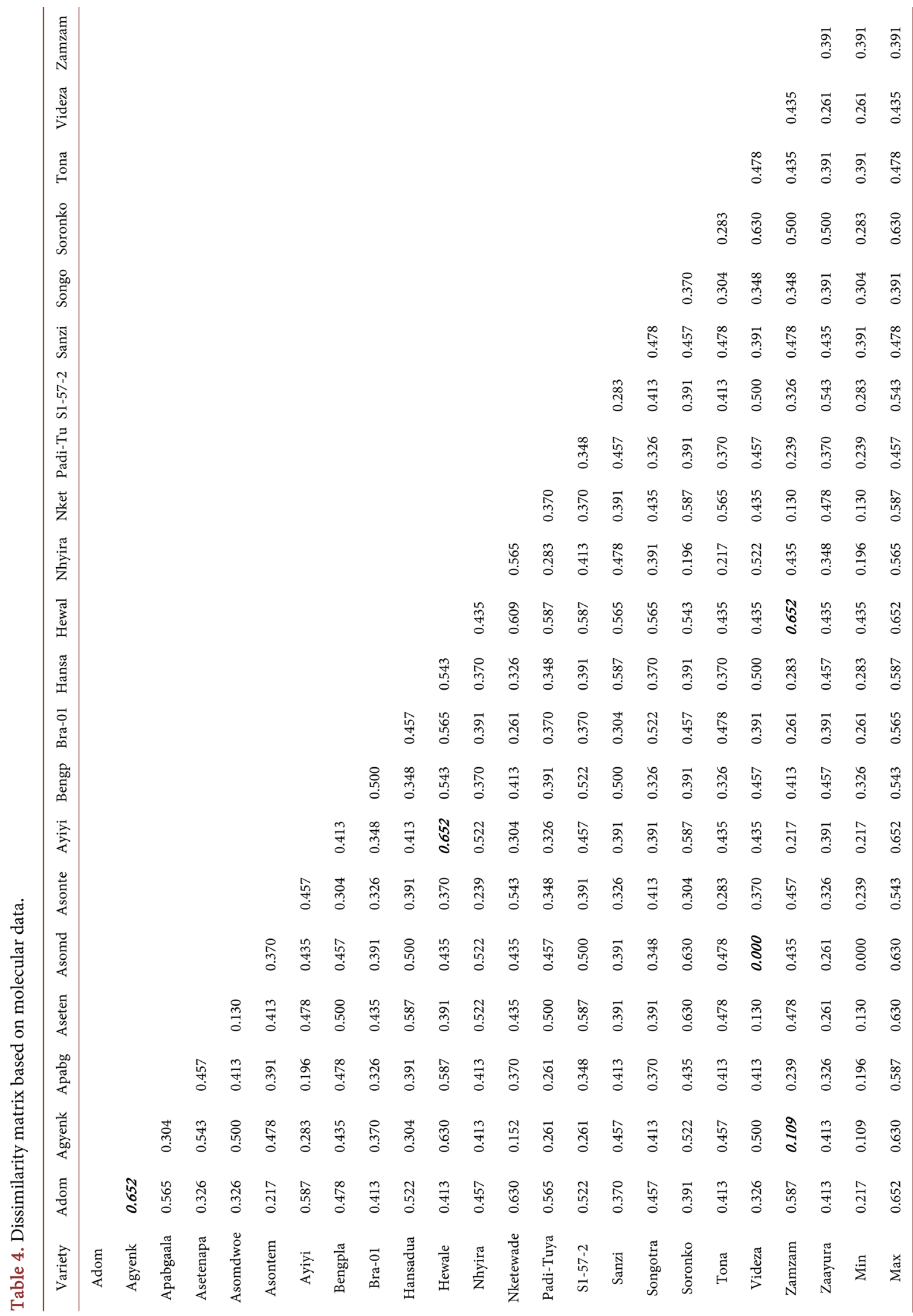


B. A. Danso et al.

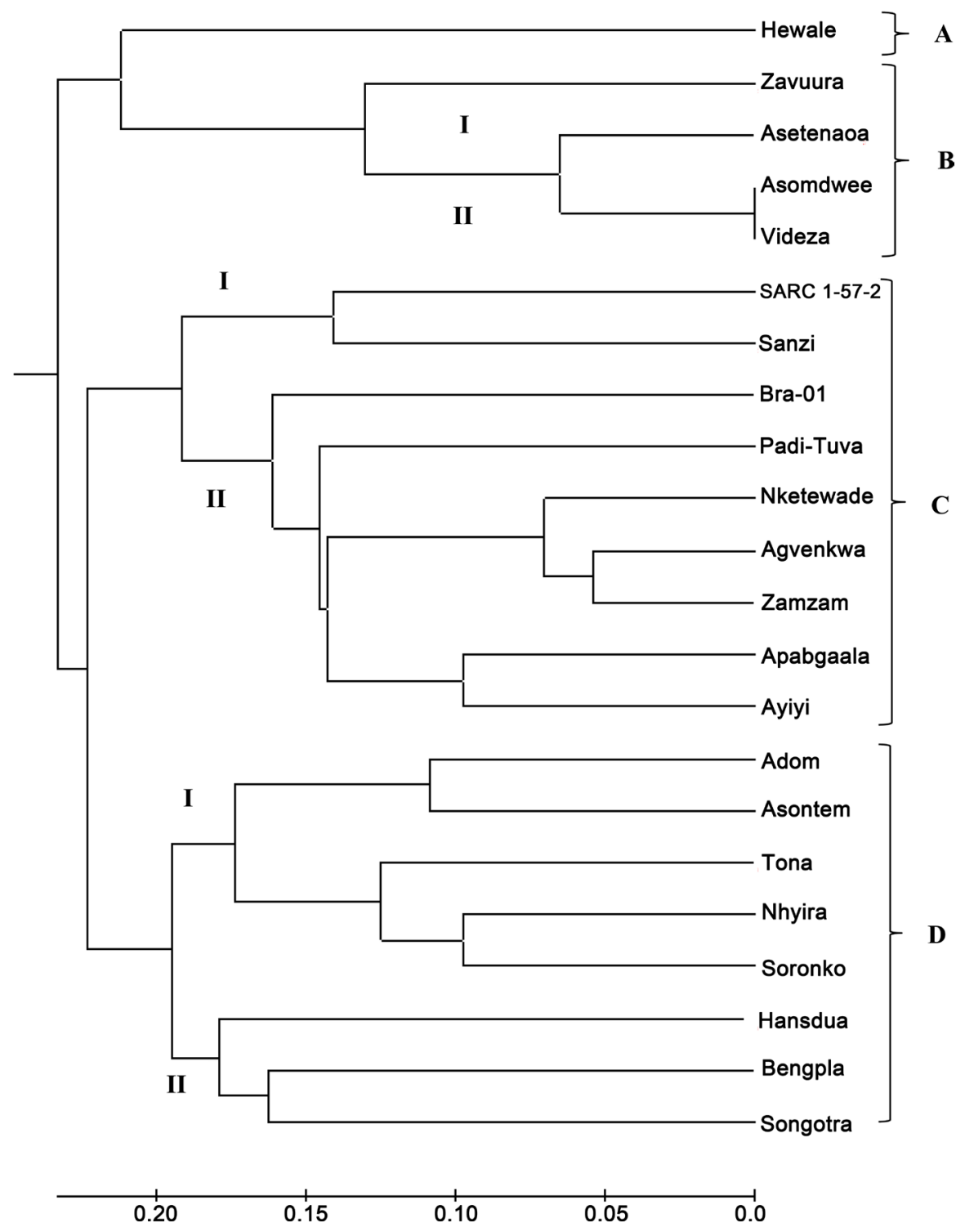

Figure 2. Dendrogram of 22 cowpea varieties using 19 SSR primers based on Unweighted Pair Group Method with Arithmetic Mean (UPGMA) generated by Darwin 6.0.010 software.

\section{Discussion}

From the study it was observed that, 19 informative SSR primer pairs produced 1 to 6 alleles per primer pair with an average of 2.53. This collaborates with the 1 to 6 alleles per primer reported by Asare et al. [9] when they assessed the genetic diversity in cowpea germplasm from Ghana using SSR primers including some of the primers used in this study. There is however, reports of number of allele per locus ranging from 1 to 9 [15], 5 to 12 [16], 1 - 16 [11], 2 to 5 [17], 5 to 12 [18] and 2 to 17 [15] in previous cowpea variability studies. According to Ali et al. [19], such variations in numbers of alleles can be attributed to the types of primers used in each study and/or the rate of polymorphism of each primer pairs. 
According to the Bostein et al. [20] scale of informativeness, PIC value $\geq 0.5$ is highly informative, 0.25 - 0.5 reasonably informative and $\leq 0.25$ is slightly informative, and marker loci with many alleles and a PIC value near 1 are most desirable. In this study, the polymorphic information content (PIC) ranged from 0.107 to 0.631 with an average of 0.293 . Asare et al. [9] also reported PIC range from 0.07 to 0.66 in a variability study of cowpea germplasm from Ghana. However, other researchers have reported PIC values in the range of 0.02 to 0.73 [21], 0.08 to 0.33 [11], 0.61 to 0.92 [18] and 0.33 to 0.83 [19]. Based on the Bostein et al. [20] scale of informativeness, the most desirable markers used in this study were SSR-6265 and SSR-6613.

Three of the primers used in this study (i.e. SSR-6258, SSR-6243 and SSR6323) were also used by Badiane et al. [11] to study the genetic relationship among cowpea varieties from Senegal. The three primers showed polymorphism just as was reported by Badiane et al. [11]. Badiane et al. [11] further observed that the primer that gave the highest allele frequency also recorded the lowest genetic diversity as well as lowest polymorphic information content (PIC). A similar situation was observed in this current study where SSR primer 6608 scored the highest allele frequency but the lowest PIC value. Previous studies conducted by Badiane et al. [11] and Doumbia et al. [18] reported low levels of polymorphism among SSR primers. This present work reports high level of polymorphism among cowpea varieties as reported also by other authors [9] [22] [23].

\section{Dissimilarity Matrix and Cluster Analysis Based on SSR-Markers}

The delineation of cowpea germplasm into groups of genetic relatedness is a valuable resource for guiding introgression efforts in breeding programmes and for improving the efficiency of germplasm management [24]. The results from the dissimilarity matrix showed that there was no distance between Videza and Asomdwoe (Table 4) implying that the two varieties are very similar. The two varieties were released by CSIR-CRI, Ghana in the year 2012. There is however enough evidence in the Catalogue of Crop varieties released and registered in Ghana [25] to prove morphological variation among the two varieties. Future fingerprinting involving these varieties should include more informative primers to detect differences within the varieties.

The dendrogram generated from the molecular data grouped the varieties into four clusters. Nketewade, Agyenkwa and Zamzam (three out of four newly released varieties by CSIR-CRI) were in the same subcluster CII (Figure 2). Adom and Asontem were found in the same subcluster DI in this study. In terms of morphology, these two varieties share several morphological traits [25]. The trend re-enforces the closeness of the two varieties. They share several characteristics in common and this may be due to the fact that they were developed from a common ancestor. Three pairs of varieties (Agyenkwa and Adom; Hewale and Ayiyi; Zamzam and Hewale) recorded high genetic distance of 0.652 
each. The varieties in each pair have different ancestry, different agro-ecological zones of production and different release times [25]. These varieties will serve as good materials from which suitable parental lines could be selected for hybridization programme.

\section{Conclusion}

This present work has provided additional molecular information about 22 cowpea varieties grown in Ghana including four newly released varieties (Agyenkwa, Zamzam, Hansadua and Nketewade). The information has been made available to CSIR-CRI and CSIR-SARI in Ghana for the purpose of varietal protection and patent right. The 19 polymorphic SSR cowpea primers were able to detect genetic diversity among cowpea germplasm grown in Ghana except for Videza and Asomdwoe. Future diversity studies involving these two varieties should include additional polymorphic primers in other to detect the differences between the two varieties.

\section{Acknowledgements}

This work was supported by research grants provided by the West Africa Agricultural Productivity Programme (WAAPP) to the Council for Scientific and Industrial Research-Crops Research Institute of Ghana. The authors wish to thank Dr Francis Kusi of CSIR-Savannah Agricultural Research Institute (SARI) for providing germplasm materials from Northern Ghana.

\section{Compliance with Ethical Standards}

\section{Conflicts of Interest}

The authors declare that there are no conflicts of interest.

\section{Datasets}

The datasets generated and analysed in this current study are available from the corresponding author on reasonable request.

\section{References}

[1] Souza, R.P., Machado, E.C., Silva, J.A.B., Lagoa, A.M.M.A. and Silveira, J.A.G. (2004) Photosynthetic Gas Exchange, Chlorophyll Fluorescence and Some Associated Metabolic Changes in Cowpea (Vigna unguiculata) during Water Stress and Recovery. Environmental and Experimental Botany, 51, 45-56.

https://doi.org/10.1016/S0098-8472(03)00059-5

[2] Singh, B.B. and Ajeigbe, H. (2007) Improved Cowpea-Cereals-Based Cropping Systems for Household Food Security and Poverty Reduction in West Africa. Journal of Crop Improvement, 19, 1-2. https://doi.org/10.1300/J411v19n01_08

[3] International Fund for Agricultural Development, IFAD (2000) Report and Recommendation of the President to the Executive Board on Proposed Technical Assistance Grants for Agricultural Research and Training by CGIAR-Supported International Centres. 69/R.27. 
[4] Xiong, H., Shi, A., Mou, B., Qin, J., Motes, D., Lu, W., Ma, J., Weng, Y., Yang, W. and Wu, D. (2016) Genetic Diversity and Population Structure of Cowpea (Vigna unguiculata L. Walp). PloS One, 11, e0160941.

https://doi.org/10.1371/journal.pone.0160941

[5] Beleke, A. and Beleke, E. (2014) Overview: Morphological and Molecular Markers Role in Crop Improvement Programs. International Journal of Current Research in Life Sciences, 3, 35-42.

[6] Bhat, K.V. (1995) DNA Fingerprinting Techniques and Cultivar Identification. National Research Centre on DNA Fingerprinting, NBPGR, New Delhi.

[7] Senior, M.L., Murphy, J.P., Goodman, M.M. and Stuber, C.W. (1998) Utility of SSRs for Determining Genetic Similarities and Relationships in Maize Using an Agarose Gel System. Crop Science, 38, 1088-1098. https://doi.org/10.2135/cropsci1998.0011183X003800040034x

[8] Milee, A., Neeta, S. and Harish, P. (2008) Advances in Molecular Techniques and Their Applications in Plant Sciences. Plant Cell Reports, 27, 617-631.

https://doi.org/10.1007/s00299-008-0507-Z

[9] Asare, A.T., Gowda, B.S., Galyuon, K.A.I., Aboagye, L., Takrama, J.F. and Timko, M.P. (2010) Assessment of the Genetic Diversity in Cowpea [Vigna unguiculata (L.) Walp.] Germplasm from Ghana Using Simple Sequence Repeat Markers. Plant Genetic Resources. Characterization and Utilization, 8, 142-150. https://doi.org/10.1017/S1479262110000092

[10] Doumbia, I.Z., Akromah, R. and Asibuo, J.Y. (2013) Comparative Study of Cowpea Germplasms Diversity from Ghana and Mali Using Morphological Characteristics. Journal of Plant Breeding and Genetics, 1.

[11] Badiane, F.A., Gowda, B.S., Cisse, N., Diouf, D., Sadio, O. and Timko, M.P. (2012) Genetic Relationship of Cowpea (Vigna unguiculata) Varieties from Senegal Based on SSR Markers. Genetics and Molecular Research, 11, 292-304. https://doi.org/10.4238/2012.February.8.4

[12] Wamala, E.N., Muoma, J. and Wekesa, C. (2016) Genetic Diversity of Cowpea ( Vigna unguiculata (L.) Walp.) Accession in Kenya Gene Bank Based on Simple Sequence Repeat Markers. International Journal of Genomics, 1-5. http://doi.org/10.1155/2016/8956412

[13] Timko, M.P. (2009) The Cowpea Genoics Knowlegde Base (CGKB). University of Virginia.

http://cowpeagenomics.med.virginia.edu/CGKB/index.pl?gene_space_read_primers

[14] Perrier, X. and Jacquemoud-Collet, J.P. (2006) DARwin Software. http://darwin.cirad.fr/darwin

[15] Diouf, D. and Hilu, K.M. (2005) Microsatellite and RAPD Markers to Study Genetic Relationships among Cowpea Breeding Lines and Local Varieties in Senegal. Genetic Resources and Crop Evolution, 52, 1957-1967.

[16] Sawadogo, M., Ouedraogo, J.T, Gowda, B.S. and Timko, M.P. (2010) Genetic Diversity of Cowpea (Vigna unguiculata L. Walp.) Cultivars in Burkina Faso Resistant to Striga gesnerioides. African Journal of Biotechnology, 9, 8146-8153. https://doi.org/10.5897/AJB10.1175

[17] Adetiloye, I.S., Ariyo, O., Alake, C.O., Oduwaye, O. and Osewa, S. (2013) Genetic Diversity of Some Selected Nigerian Cowpea Using Simple Sequence Repeats (SSR) Marker. African Journal of Agricultural Research, 8, 586-590. http://www.academicjournals.org/ajar

[18] Doumbia, I.Z., Akromah, R.A. and Asibuo, J.Y. (2014) Assessment of Cowpea 
Germplasms from Ghana and Mali Using Simple Sequence Repeat (SSR) Markers. International Journal of Agriculture and Forestry, 4, 118-123.

[19] Ali, Z.B., Yao, K.N., Odeny, D.A., Kyalo, M., Skilton, R. and Eltahir, I.M. (2015) Assessing the Genetic Diversity of Cowpea [Vigna unguiculata (L.) Walp.] Accessions from Sudan Using Simple Sequence Repeat (SSR) Markers. African Journal of Plant Science, 9, 293-304. https://doi.org/10.5897/AJPS2015.1313

[20] Botstein, D., White, R.L., Skolnick, M. and Davis, R.M. (1980) Construction of a Genetic Linkage Map in Man Using Restriction Fragment Length Polymorphisms. The American Journal of Human Genetics, 32, 314-331.

[21] Li, C.D., Fatokun, C.A., Ubi, B., Singh, B.B. and Scoles, G.J. (2001) Determining Genetic Similarities and Relationship among Cowpea Breeding Lines and Cultivars by Microsatellite Markers. Crop Science, 41, 189-197. https://doi.org/10.2135/cropsci2001.411189x

[22] Afiukwa, C.A., Kunert, K.J., Vorster, J., Cullis, C.A. and Ubi, B.E. (2011) Microsatellite Association with Seed Protein Content and Flowering Time in Nigerian Cowpea Cultivars. African Journal of Biotechnology, 10, 18064-18064.

[23] Choumane, W., Winter, P., Weig, F. and Kahl, G. (2000) Conservation and Variability of Sequence Tagged Microsatellites Sites (STMSs) from Chickpea (Cicer aerietinum L.) within the Genus Cicer. Theoretical and Applied Genetics, 101, 269-278. https://doi.org/10.1007/s001220051479

[24] Huynh, B.-L., Close, T.J., Roberts, P.A., Hu, Z., Wanamaker, S., Lucas, M.R., et al. (2013) Gene Pools and the Genetic Architecture of Domesticated Cowpea. The Plant Genome, 6.

[25] National Variety Release and Registration Committee (2015) Catalogue of Crop Varieties Released and Registered in Ghana. Vol. 1. 